\title{
Returns to Education in South Africa: Evidence from the National Income Dynamics Study
}

\author{
Craig Depken* \\ Chanda Chiseni ${ }^{* *}$ \\ Ernest Ita***
}

\begin{abstract}
We utilize two waves of the National Income Dynamics Study in South Africa to estimate the returns to education in 2010 and 2012. We find that during this time period the returns to education were approximately $18 \%$ per year of education and that the returns were higher for females relative to males and higher for those living in urban relative to rural areas. The policy implications include a suggestion to continue investment in educational infrastructure, especially in rural areas, so as to increase the returns to education in those areas.
\end{abstract}

Keywords: instrumental variables; Mincer equations; developing countries

JEL Classification: 126, J31

\section{Introduction}

Since the 1990s, many African countries have invested heavily in education, with the aim of ending the poverty cycle that has characterized much of Africa since colonial times. Yet, Söderbom et al. (2006) indicate that there is evidence that an increased investment in education has brought about a decrease in the returns to education in most African countries.

Many African countries have invested more in primary education than in higher levels of education. Psacharopoulous (1994) shows that returns to schooling are higher at lower levels of education relative to higher levels of education. Some researchers

\footnotetext{
* Craig Depken is at UNC Charlotte, Charlotte, NC, USA.

** Chanda Chiseni is at Lund University, Lund, Sweden.

**** Ernest Ita is at Department of Economics, UNC Charlotte, Charlotte, NC, USA.
} 
have documented a concave earnings function but Söderbom et al. (2006) argue that recent evidence shows that the earnings function is convex. This would mean that the returns to schooling are lower for individuals with lower levels of education and that the returns to education increase with education.

Indeed, even as the current South African government endeavors to ameliorate the education inequalities that were created and perpetuated during the apartheid era (Letseka, 2014), it is necessary for policy makers to have an understanding of the pervasive educational inequalities that still plague South Africa. This paper makes a contribution in that we estimate returns to education for more sub-populations than in previous studies.

In this paper, we investigate the returns to education in South Africa using two waves of the National Income Dynamics Study (NIDS) from the years 2010 and 2012. To control for ability bias, we utilize an instrumental variable approach using father's and mother's education as instruments for an individual's education to control for ability bias. A large literature has documented that a parent's education greatly influences a child's education, which influences the child's earnings later in life. During the sample period, the returns to education in South Africa were estimated at $18.1 \%$, females had higher returns to education relative to men, and returns to education were higher in urban areas relative to rural areas.

\section{Literature Review}

Since the 1970s, a large literature has developed documenting the nexus between education and earnings. Knowledge of the returns to education is valuable because it can help inform educational policy. A popular approach is to estimate the relationship between education and earnings in a Mincerian framework (Mincer, 1974). Psacharopoulos (1994) uses this estimation strategy to estimate the impact of education on wages for 62 countries and finds a strong positive correlation between education and wages. For the Sub-Saharan countries included in his study, he finds that an additional year of education increases wages by $8 \%-20 \%$. Psacharopoulos and Patrinos (2018) analyze trends and patterns of the estimated returns to education for 219 countries from 1950-2014 and find that the average estimated returns to an additional year of schooling is approximately $9 \%$ and that the returns to education for females exceeds that of males.

Schultz (2004) estimates the returns to education in six African countries for the period 1985-1999. He finds a large difference in the returns to education between males and females at different levels of education. He also finds that the returns to education were higher in secondary levels relative to the post-secondary level, consistent with the general findings of Psacharopoulos and Patrinos (2018). 
Salisbury (2016) estimates both the private and the social returns to schooling in South Africa in the post-Apartheid era. He analyzes whether the returns for black South Africans and coloured (mixed-race) South Africans have improved since the initial 1990s post-apartheid era. He finds a large improvement in the returns to education for both black and coloured South Africans compared to the apartheid era. His evidence suggests that white South Africans still have higher returns to education than black and coloured South Africans ${ }^{1}$.

Kuepie et al. (2009) estimate the private returns to education in urban West Africa, in Abidjan, Bamako, Cotonou, Dakar, Lomé, Niamey, and Ouagadougou. Their evidence shows convex returns to education in these cities in all the sectors, including the informal sector. They also show an increase in earnings when individuals move from secondary schools to post-secondary schools.

Fryer and Vencatachellum (2005) investigate the returns to education for black South African women in the Machibisa township of Kwa Zulu Natal. After controlling for labor-specific factors, they find that primary education is not a reliable predictor of employment status that the returns to education are $0.30 \%$ for the first two years of secondary school education, and secondary school graduates are more likely to find employment in the government sector than any other sector.

Using a two-stage estimation procedure, Case and Yogo (1999) estimate how returns to education in South Africa are affected by school characteristics. Using data from the 1996 South African census and two national surveys of school quality, they present evidence showing that the quality of a school has a large and significant impact on the returns to schooling especially for black South African males.

Casale and Posel (2011) use the first wave of the National Income Dynamics panel survey of 2008 to explore the nexus between English language proficiency and earnings in South Africa. She concludes that there are large returns to reading and writing among black South Africans.

Keswell and Poswell (2004) used three data sets to estimate returns to education in South Africa, namely: Project for Statistics Living Standards and Development (PSLSD) 1993, the 1995 and 1997 October Household Surveys (OHS) and the September 2000 Labour Force Survey (LFS) data. They present evidence showing a strong convex relationship between education and earnings in South Africa contrary to the conventional human capital theory. The results imply that the returns to education increase with the level of schooling attained in South Africa. They also conclude that the returns to schooling in South Africa in 1993 were twice as high for non-whites relative to whites and returns were higher at higher levels of schooling for both cohorts. 


\section{Methodology and Data}

\section{Methodology}

Mincer (1974) posited that at any particular point an individual's earnings could be estimated as a concave function of the individual's labor market experience:

$$
\text { logWage }_{\mathrm{it}}=\mathrm{b}_{0}+\mathrm{b}_{1} \mathrm{EDU}_{\mathrm{it}}+\mathrm{b}_{2} \mathrm{AGE}_{\mathrm{it}}+\mathrm{b}_{3} \mathrm{AGESQUARED}_{\mathrm{it}}+\theta \mathrm{X}_{\mathrm{it}}+u_{\mathrm{it}}
$$

where the $\beta$ 's and $\theta$ are parameters to be estimated, $i$ indexes individuals, $t$ indexes year, and $u$ is a white noise error term.

The Mincer equation was the result of his investigation into the distribution of wages in the population. Rather than considering an individual's wage as a function of luck and connections, Mincer posited that both education and post-education experience, proxied by age, contributed to an individual's wage. For more than fifty years, the Mincer equation has been applied to numerous samples and estimation strategies, most recently outlined in Psacharopoulos and Patrinos (2018) which reviews the global returns to education literature. While there have been criticisms of the Mincer equation, especially concerns about endogeneity of the level of education obtained by an individual (see Card, 1995 and 1999, and Polachek, 2007), the approach is surprisingly robust, compact in its specification, and flexible enough to allow for differences in the returns to human capital across gender, race, and geography.

Follow Palachek (2007), we use AGE and AGESQUARED to proxy for posteducation and labor market experience. Included in the matrix of control variables, $\boldsymbol{X}$, are three categorical variables that measure race: COLOURED, ASIAN/INDIAN, and WHITE (BLACK is the reference category). We also include whether the individual is female (FEMALE), the individual's marital status (MARRIED), whether the individual lives in an urban area $(U R B A N)$, and whether the individual is selfemployed (SELFEMPLOYED). Finally, we include a series of categorical variables that capture the level of "gangsterism" in the area in which the individual lives. On the one hand, where there are high levels of gangsterism wages might be higher as a form of compensating differential. On the other hand, where there are high levels of gangsterism wages might be lower because labor is less productive and the output of labor is less secure and therefore has lower expected value. We include four variables that reflect that gangsterism is Very Rare, Not Common, Fairly Common, or Very Common (Never Happens is the reference category).

\section{Data}

We utilize two waves of the National Income Dynamics Study (NIDS) from 2010 and 2012. The NIDS includes a nationally representative sample of over 28,000 
individuals in 7,300 households across South Africa. The survey is repeated with the same household members every two years. The NIDS examines the livelihoods of individuals and households over time.

We are not the first to use these data. Biyase and Zwane (2015) use a dynamic panel data estimator to estimate the returns to education in South Africa from 20082012; they find that the returns to an additional year of education is approximately $47 \%$. While there is increasing skepticism about the veracity of panel models that use lagged dependent variables as instruments, we use Biyase and Zwane as a benchmark to which we compare our estimated returns to education in various sub-populations of South Africa.

Our sample is restricted to 4,481 observations because of missing values in many of the variables included in our model. Table 1 reports the descriptive statistics of the sample we use. The average log wages is 2.93 , average education is approximately nine years, average age is approximately 43 years, 14 percent of the sample is coloured, 1 percent of the sample is Asian/Indian, and 6 percent of the sample is white (the remaining portion of the sample is comprised of blacks). Approximately 51 percent of the sample is female, 44 percent is married, 59 percent is urban, and 13 percent is self-employed. Regarding the level of gangsterism where the individual lives, 21 percent of the sample reported gangsterism is "very rare," 20 percent that gangsterism is "not common," 12 percent that gangsterism is "fairly common," and 15 percent that gangsterism is "very common" (the remaining portion of the sample reported that gangsterism "never happens"). Approximately $60 \%$ of the sample is from the year 2010 .

Table 1: Descriptive Statistics of the Data

\begin{tabular}{|l|r|r|r|r|}
\hline Variable & \multicolumn{1}{|c|}{ Mean } & Std. Deviation & Minimum & Maximum \\
\hline lnWages & 2.934 & 1.235 & -3.658 & 9.574 \\
\hline Education & 9.15 & 4.20 & 0 & 17 \\
\hline Age & 42.68 & 11.07 & 16 & 82 \\
\hline Coloured & 0.143 & 0.351 & 0 & 1 \\
\hline Asian/Indian & 0.014 & 0.116 & 0 & 1 \\
\hline White & 0.066 & 0.249 & 0 & 1 \\
\hline Female & 0.509 & 0.499 & 0 & 1 \\
\hline Married & 0.443 & 0.496 & 0 & 1 \\
\hline Urban & 0.586 & 0.492 & 0 & 1 \\
\hline Self Employed & 0.134 & 0.341 & 0 & 1 \\
\hline Gangsterism Very Rare & 0.214 & 0.411 & 0 & 1 \\
\hline Gangsterism Not Common & 0.200 & 0.400 & 0 & 1 \\
\hline Gangsterism Fairly Common & 0.124 & 0.330 & 0 & 1 \\
\hline Gangsterism Very Common & 0.155 & 0.362 & 0 & 1 \\
\hline Year 2010 & 0.597 & 0.491 & 0 & 1 \\
\hline
\end{tabular}

Notes: N=4,481 observations from 2010 and 2012 waves of the South African National Income Dynamics Study (NIDS). 


\section{Estimation Results}

Column 1 of Table 2 reports the preliminary analysis using ordinary least squares (OLS). The OLS estimate on the returns to education in South Africa is $11.3 \%$. The control variables indicate that wages increase with age but at a decreasing rate, coloured South Africans earn less than black South Africans, and Asian/Indians and whites earn more than black South Africans. Females earn approximately $29 \%$ less than males, those who are married earn approximately $17 \%$ more, and those who are self-employed earn 37\% less. Gangsterism does not influence average wages unless it is deemed to be "very common," in which case the average wage drops an estimated $14 \%$.

Table 2: OLS and Instrumental Variables Results

\begin{tabular}{|c|c|c|}
\hline & OLS & IV \\
\hline VARIABLES & lnwages & lnwages \\
\hline \multirow[t]{2}{*}{ Education } & $0.113 * * *$ & $0.184 * * *$ \\
\hline & $(0.005)$ & $(0.014)$ \\
\hline \multirow[t]{2}{*}{ Age } & $0.044 * * *$ & $0.046^{* * *}$ \\
\hline & (0.009) & $(0.010)$ \\
\hline \multirow[t]{2}{*}{ Age squared } & $-0.000 * * *$ & $-0.000 * *$ \\
\hline & $(0.000)$ & $(0.000)$ \\
\hline \multirow[t]{2}{*}{ Coloured a $^{2}$} & $-0.216^{* * *}$ & $-0.178^{* * *}$ \\
\hline & $(0.046)$ & $(0.048)$ \\
\hline \multirow[t]{2}{*}{ Asia/Indian } & $0.222 *$ & 0.059 \\
\hline & $(0.127)$ & $(0.127)$ \\
\hline \multirow[t]{2}{*}{ White } & $0.517 * * *$ & $0.241 * * *$ \\
\hline & $(0.061)$ & $(0.079)$ \\
\hline \multirow[t]{2}{*}{ Female (1=Yes) } & $-0.287 * * *$ & $-0.325^{* * *}$ \\
\hline & $(0.031)$ & $(0.033)$ \\
\hline \multirow[t]{2}{*}{ Married (1=YES) } & $0.171 * * *$ & $0.092 * *$ \\
\hline & $(0.036)$ & $(0.039)$ \\
\hline \multirow[t]{2}{*}{ Urban (1=Yes) } & $0.270 * * *$ & $0.123 * * *$ \\
\hline & $(0.037)$ & $(0.046)$ \\
\hline \multirow[t]{2}{*}{ Self-employed (1=YES) } & $-0.371^{* * *}$ & $-0.351^{* * *}$ \\
\hline & (0.056) & $(0.058)$ \\
\hline \multirow[t]{2}{*}{ Gangsterism Very Rare ${ }^{\text {b }}$} & 0.047 & 0.031 \\
\hline & $(0.047)$ & $(0.047)$ \\
\hline \multirow[t]{2}{*}{ Gangsterism Not Common } & -0.035 & -0.034 \\
\hline & $(0.047)$ & $(0.048)$ \\
\hline
\end{tabular}


Table 2. Continued

\begin{tabular}{|c|c|c|}
\hline & OLS & IV \\
\hline \multirow[t]{2}{*}{ Gangsterism Fairly Common } & -0.078 & -0.077 \\
\hline & (0.058) & $(0.059)$ \\
\hline \multirow[t]{2}{*}{ Gangsterism Very Common } & $-0.140^{* * *}$ & $-0.124 * * *$ \\
\hline & $(0.056)$ & $(0.057)$ \\
\hline \multirow[t]{2}{*}{ Year 2010} & 0.233 & $0.252 * * *$ \\
\hline & $(0.035)$ & $(0.036)$ \\
\hline \multirow[t]{2}{*}{ Constant } & $0.517 * * *$ & -0.249 \\
\hline & $(0.205)$ & $(0.249)$ \\
\hline F-test for education not endogenous & & $28.789 * * *$ \\
\hline Anderson-Rubin Test ${ }^{\mathrm{c}}$ & & $81.98 * * *$ \\
\hline Kleibergen-Paap Test $^{\mathrm{d}}$ & & $464.72 * * *$ \\
\hline Sanderson-Windmeijer Test ${ }^{\mathrm{e}}$ & & $380.46^{* * *}$ \\
\hline Cragg-Donald Test ${ }^{\mathrm{f}}$ & & $285.31 * * *$ \\
\hline Hansen Test for Instrument Validity ${ }^{\mathrm{g}}$ & & 0.001 \\
\hline Observations & 4,481 & 4,481 \\
\hline R-squared & 0.269 & 0.227 \\
\hline
\end{tabular}

Notes: ${ }^{a}$ Reference category is black. ${ }^{b}$ Reference category is Gangsterism Never Happens. ${ }^{\mathrm{c}}$ Test for endogeneity of education. ${ }^{\mathrm{d}}$ Test for under identification or failure to satisfy order condition. ${ }^{\mathrm{e}}$ Test of weak excluded instruments. ${ }^{\mathrm{f}}$ test of weak excluded instruments. ${ }^{\mathrm{g}}$ Test for instrument validity. Education instrumented with mother's and father's education. Standard errors clustered by household reported in parentheses. $* * * \mathrm{p}<0.01, * * \mathrm{p}<0.05, * \mathrm{p}<0.10$

The potential for education to be endogenous can arise if there anything innate to the individual might influence both an individual's wages and their chosen level of education, for instance, work ethic or self-motivation. In recent studies, parent's education has been used as an instrumental variable to control for innate ability. Haveman and Wolfe (1995) postulate that a parent's education is one of the most pertinent factors that influences a child's success in school perhaps through assertive mating or because educated parents have the means to help their children be academically successful (see Holmlund et al., 2011, for a review). Oreopoulos et al. (2006) utilize mandatory schooling reforms that took place in the various United States to estimate the influence of mother and father education on grade repetition. They find that controlling for an individual's parent's education has a large impact on grade repetition. Further, many studies postulate that the role of a father in the nurturing process has a larger effect on the child's schooling relative than that of the mother (see, for example, Ashenfelter and Rouse, 1998).

Given these previous findings we use both mother's and father's education as instrumental variables in estimating the returns to education in South Africa. The following regression model gives initial evidence of instrument relevance, where standard errors clustered at the household level are reported in parentheses: 


$$
\text { EDUCATION }_{i}=\begin{aligned}
& 7.430 \\
& (0.07)
\end{aligned}+\begin{aligned}
& 0.264 M E D U C_{i} \\
& (0.02)
\end{aligned}+\begin{aligned}
& 0.231 F E D U C_{i} \\
& (0.02)
\end{aligned}
$$

where MEDUC indicates mother's education and FEDUC is father's education for individual $i$. In the above regression, all three parameters are statistically meaningful with $\mathrm{p}<0.00$ and the F-stat of joint significance is 755.03 , $\mathrm{p}<0.00$. We test for endogeneity using a Wu-Hausman test and reject the null of no endogeneity (F-test statistic of 33.33, $\mathrm{p}<0.000$ ). This suggests that an instrumental variables approach is justified.

However, when using instrumental variables there are at least three concerns. First, is whether the instrumental variables estimation is fully identified by satisfying the rank and order conditions. While the rank condition is satisfied by having more proposed instruments than endogenous variables, the order condition is not necessarily satisfied by exclusionary restrictions. We report the Kleibergen-Paap under-identification test for the instrumental variables estimator in Table 2. We reject the null hypothesis of under-identification and conclude that both the rank and order conditions are met in our instrumental variables estimation.

The next concern is the so-called weak instruments problem, which has been shown by Bound, Jaeger, and Baker (1993 and 1995) to potentially exacerbate any bias exhibited into OLS. One test of weak instruments is the afore-mentioned $\mathrm{F}>10$ rule of thumb on the excluded instruments from the first-stage regression and attributed to Staiger and Stock (1997). We reject the heuristic of weak instruments. An alternative is to consider the Stock and Yogo (2005) weak instruments adjusted critical values for the F-statistics from the model. In this case we reject the null of weak instruments at conventional significance levels.

The final concern is instrument validity. While we have shown above that our two proposed instruments are relevant in that they are related to the individual's education level, validity focuses on whether the instruments can be considered truly exogenous from the system. While it is impossible to directly test whether any particular instrument is actually exogenous from the error term in the wage equation, it is possible to use a Hansen test of the null that the instruments as a group are coherent with exogeneity. We report the Hansen test for instrument validity in Table 2. It is easy to see that the two instruments appear to be coherent with exogeneity.

Therefore, we believe that the intuition underlying our instruments, coupled with the statistical diagnostics of the instrumental variables estimation, combine to provide consistent estimation results. If our case has been made, then the returns to education in South Africa in 2010 and 2012 are estimated to have a 95\% confidence interval of $[0.15,0.21]$ centered on 0.18 compared to the OLS estimate of 0.11 .

We also control for many other characteristics of the individual and their life situation. Wages increase with age but at a decreasing rate. From the instrumental variables estimation, we find that coloured individuals are paid approximately $18 \%$ 
less than blacks on average, Asian/Indians are paid no differently than blacks on average, whereas whites are paid approximately $24 \%$ more than blacks on average. Women are paid approximately $33 \%$ less than males, those who are married are paid approximately $9 \%$ more, those who live in urban areas are paid approximately $12 \%$ more, those who are self-employed earn approximately $35 \%$ less, and gangsterism negatively influences wages when it is "very common." Finally, wages were approximately $25 \%$ higher in 2010 relative to 2012 .

In Table 3 we present results from estimating the wage equation separately for males and females (columns two and three) and separately for those who live in urban and rural areas (columns four and five). The expectation is that there are differences across these four groups because of structural differences in how wages are determined for individuals in each group. Column two shows returns to education for females and Column three for males. It is evident that the returns to education in South Africa during the sample period are higher for females than for males, 21.2\% and $15.0 \%$, respectively. This result is consistent with the fact that males often drop out of school to work while females often remain in school. Column four shows returns to education in urban areas and column five for rural areas. The returns to education in South Africa during the sample period are higher in urban areas than in rural areas, $21.4 \%$ and $13.8 \%$, respectively. This result is not surprising in that South Africa still experiences the persistent effects of Apartheid. Because of this, many people in rural areas remain under-educated as they lack access to a well-established academic infrastructure.

Table 3: Differences between Male-Female and Urban-Rural

\begin{tabular}{|l|c|c|c|c|}
\hline & Females & Males & Urban & Rural \\
\hline VARIABLES & lnwages & lnwages & lnwages & lnwages \\
\hline Education & $0.212^{* * *}$ & $0.150^{* * *}$ & $0.214 * * *$ & $0.138^{* * *}$ \\
\hline & $(0.017)$ & $(0.023)$ & $(0.018)$ & $(0.021)$ \\
\hline Age & $0.030^{* *}$ & $0.058^{* * *}$ & $0.042^{* * *}$ & $0.048^{* * *}$ \\
\hline & $(0.014)$ & $(0.013)$ & $(0.014)$ & $(0.013)$ \\
\hline Age squared & 0.000 & $-0.000^{* * *}$ & -0.000 & $-0.000^{* *}$ \\
\hline & $(0.000)$ & $(0.000)$ & $(0.000)$ & $(0.000)$ \\
\hline Coloured ${ }^{a}$ & -0.098 & $-0.229 * * *$ & $-0.180^{* * *}$ & $-0.229 * * *$ \\
\hline & $(0.071)$ & $(0.061)$ & $(0.058)$ & $(0.087)$ \\
\hline Asian/Indian & -0.173 & 0.261 & -0.016 & 0.055 \\
\hline & $(0.146)$ & $(0.191)$ & $(0.155)$ & $(0.196)$ \\
\hline White & $0.242^{* *}$ & $0.285^{* *}$ & 0.114 & $0.575^{* *}$ \\
\hline & $(0.097)$ & $(0.124)$ & $(0.087)$ & $(0.227)$ \\
\hline Female (1=Yes) & & & $0.214 * * *$ & $0.138^{* * *}$ \\
\hline & & & $(0.018)$ & $(0.021)$ \\
\hline
\end{tabular}


Table 3. Continued

\begin{tabular}{|c|c|c|c|c|}
\hline & Females & Males & Urban & Rural \\
\hline \multirow[t]{2}{*}{ Married (1=Yes) } & 0.066 & $0.138^{* *}$ & $0.099 * *$ & $0.126^{*}$ \\
\hline & $(0.052)$ & $(0.062)$ & $(0.050)$ & $(0.064)$ \\
\hline \multirow[t]{2}{*}{ Urban (1=Yes) } & 0.053 & $0.200^{* * *}$ & & \\
\hline & $(0.061)$ & $(0.070)$ & & \\
\hline \multirow[t]{2}{*}{ Self-employed (1=Yes) } & $-0.396^{* * *}$ & $-0.286^{* * *}$ & $-0.325^{* * *}$ & $-0.372 * * *$ \\
\hline & $(0.084)$ & $(0.078)$ & $(0.083)$ & $(0.079)$ \\
\hline \multirow[t]{2}{*}{ Gangsterism Very Rare ${ }^{b}$} & 0.044 & 0.024 & 0.055 & 0.061 \\
\hline & $(0.068)$ & $(0.064)$ & $(0.065)$ & $(0.075)$ \\
\hline \multirow[t]{2}{*}{ Gangsterism Not Common } & -0.079 & 0.011 & $-0.135^{* *}$ & 0.115 \\
\hline & $(0.065)$ & $(0.066)$ & $(0.064)$ & $(0.071)$ \\
\hline \multirow[t]{2}{*}{ Gangsterism Fairly Common } & -0.089 & -0.048 & $-0.185^{* *}$ & 0.159 \\
\hline & $(0.083)$ & $(0.081)$ & $(0.075)$ & $(0.100)$ \\
\hline \multirow[t]{2}{*}{ Gangsterism Very Common } & -0.058 & $-0.201 * *$ & $-0.161^{* *}$ & 0.039 \\
\hline & $(0.074)$ & $(0.082)$ & $(0.077)$ & $(0.093)$ \\
\hline \multirow[t]{2}{*}{ Year 2010} & $0.265^{* * * *}$ & $0.243^{* * * *}$ & $0.253 * * *$ & $0.237 * * *$ \\
\hline & $(0.049)$ & $(0.050)$ & $(0.048)$ & $(0.054)$ \\
\hline \multirow[t]{2}{*}{ Constant } & -0.553 & -0.144 & -0.343 & 0.115 \\
\hline & $(0.336)$ & $(0.375)$ & $(0.361)$ & $(0.377)$ \\
\hline F-test for education not endogenous & $29.30 * * *$ & $5.08 * * *$ & $25.86^{* * * *}$ & $4.58 * * *$ \\
\hline Anderson-Rubin Test ${ }^{c}$ & $78.55^{* * * *}$ & $19.47 * * *$ & $62.23 * * *$ & $21.56^{* * * *}$ \\
\hline Kleibergen-Paap Test ${ }^{\mathrm{d}}$ & $308.60 * * *$ & $192.88^{* * * *}$ & $282.34 * * *$ & $191.05 * * *$ \\
\hline Sanderson-Windmeijer Test ${ }^{\mathrm{e}}$ & $262.34 * * *$ & $145.13 * * *$ & $214.13^{* * *}$ & $178.17 * * *$ \\
\hline Cragg-Donald Test ${ }^{\mathrm{f}}$ & $183.76^{* * * *}$ & $106.95 * * *$ & $180.95 * * *$ & $117.87 * * *$ \\
\hline Hansen Test for Instrument Validity ${ }^{\mathrm{g}}$ & 0.32 & 0.93 & 0.45 & 1.43 \\
\hline Observations & 2,282 & 2,199 & 2,626 & 1,855 \\
\hline R-squared & 0.216 & 0.225 & 0.193 & 0.187 \\
\hline
\end{tabular}

Notes: ${ }^{a}$ Reference category is black. ${ }^{\mathrm{b}}$ Reference category is Gangsterism Never Happens. ${ }^{\mathrm{c}}$ F-test that education is not endogenous. ${ }^{\mathrm{d}}$ Chi-squared test for under identification or failure to satisfy order condition. ${ }^{\mathrm{e}} \mathrm{F}$-test of weak excluded instruments. ${ }^{\mathrm{f}}$ F-test of weak excluded instruments. ${ }^{\mathrm{g}}$ Chi-squared test for instrument validity. Education instrumented with mother's and father's education. Standard errors clustered by household reported in parentheses. $* * * \mathrm{p}<0.01, * * \mathrm{p}<0.05, * \mathrm{p}<0.10$. 


\section{Conclusions}

This study investigates the returns to education in South Africa during 2010 and 2012 using both ordinary least squares and instrumental variables. We show that education is likely endogenous thereby rendering the ordinary least squares results inconsistent. We use mother's and father's education as instruments for an individual's education level and find that the returns to education on average are estimated at $18.4 \%$, approximately $62 \%$ greater than the estimated impact from ordinary least squares.

The knowledge of returns to education between urban and rural areas and across gender gives policy makers some insight on where they should focus in terms of education policy. For example, it shows that returns to education are higher in urban areas than in rural areas. In retrospect, it is important for the South African government to create more opportunities for individuals that live in rural areas to access good quality education especially at lower levels of education. The evidence from this study indicates that the returns to education in South Africa is $18.1 \%$. While this estimate is high compared to many other African and Western countries, it suggests that there are considerable gains to be had if there is an increase in educational attainment among the South African population.

\section{NOTES}

${ }^{1}$ Posel (2001) states that "[T]he architects of apartheid racial classification policies in South Africa, recognized explicitly that racial categories where social constructs, rather than descriptors of real essence." The South African government designed and implemented racial classification as state policy to control its population (Khalfani and Zuberi, 2001). Four distinct races can be found in South Africa, white people, coloured people (who are a mixture of two or more races), black people (the native black South Africans), and Indian/Asian people.

\section{REFERENCES}

Ashenfelter, Orley and Ceclia Rouse (1998), "Income, Schooling, and Ability: Evidence from a New Sample of Identical Twins," The Quarterly Journal of Economics, 113(1), 253-284.

Biyase, Mduduzi and Talent Zwane (2015), "Does Education Pay in South Africa? Estimating Returns to Education Using Two Stage Least Squares Approach,” International Business \& Econmics Research Journal, 14(6), 807-814.

Bound, John, David A. Jaeger, and Regina Baker (1993). "The Cure Can Be Worse than the Disease: A Cautionary Tale Regarding Instrumental Variables,” NBER Technical Working Paper No. 137.

Bound, John, David A. Jaeger, and Regina Baker (1995), "Problems with Instrumental Variables Estimation when the Correlation between the Instruments and the Endogenous Explanatory Variables is Weak," Journal of the American Statistical Association, 90(430), 443-450. 
Card, David (1995), "Earnings, Schooling and Ability Revisited," Research in Labor Economics, 14:23-48.

Card, David (1999) “The Causal Effect of Education on Earnings," in Handbook of Labor Economics, Orley Ashenfelter and David Card eds.,Elsevier Press: Amsterdam, 1801-1863.

Case, Anne and Motohiro Yogo (1999), "Does School Quality Matter? Returns to Education and the Characteristics of Schools in South Africa," NBER Working Paper No. 7399.

Casale, Daniela and Dorrit Posel (2011), "English Language Proficiency and Earnings in a Developing Country: The Case of South Africa," The Journal of Socio-Economics, 40(4), 385-393.

Davenport, T.R.H. (1991), South Africa: A Modern History, 4th ed., London: MacMillan.

Fryer, David and Desire Vencatachellum (2005), "Returns to Education in South Africa: Evidence from the Machibisa Township," African Development Review, 17(3), 513-535.

Holmlund, Helena, Mikael Lindahl, and Erik Plug (2011), "The Causal Effect of Parent's Schooling on Children's Schooling: A Comparison of Estimation Methods," Journal of Economic Literature, 49(3), 615-651.

Haveman, Robert and Barbara Wolfe (1995), "The Determinants of Children Attainments: A Review of Methods and Findings," Journal of Economic Literature, 33(4), 1829-1878.

Keswell, Malcom and Laura Poswell (2004), "Returns to Education in South Africa: A Retrospective Sensitivity Analysis of the Available Evidence," South African Journal of Economics, 72(4), 834-860.

Khalfani, Akil Kokayi and Tukufu Zuberi (2001), "Racial Classification and the Modern Census in South Africa, 1911-1996,” Race and Society, 4(2), 161-176.

Kuepie, Mathias, Christophe Nordman, and Francois Roubaud (2009), "Education and Earnings in Urban West Africa," Journal of Comparative Economics, 37(3), 491-515.

Letseka, Moeketsi (2014), "The Illusion of Education in South Africa," Procedia - Social and Behavioral Sciences, 116, 4864-4869.

Mincer, Jacob (1974), Schooling, Experience, and Earnings, National Bureau of Economic Research.

Oreopoulos, Philip, Marianne Page, and Anne Huff Stevens (2006), "The Intergenerational Effects of Compulsory Schooling,” Journal of Labor Economics, 24(4), 729-760.

Polachek, Solomon (2007), "Earnings over the Lifecycle: The Mincer Earnings Function and its Applications," IZA working paper, No. 3181.

Posel, Deborah (2001), "Race as Common sense: Racial classification in Twentieth-Century South Africa," African Studies Review, 44(2), 87-113.

Psacharopoulos, George (1994), "Returns to Investment in Education: A Global Update," World Development, 22(9), 1325-1343.

Psacharopoulos, George and Harry Anthony Patrinos (2018), "Returns to Investment in Education: A Decennial Review of the Global Literature," Education Economics, 26(5), 445-458.

Salisbury, Taylor (2016), "Education and inequality in South Africa: Returns to schooling in the postapartheid era," International Journal of Educational Development, 46(1), 43-52.

Schultz, T. Paul (2004), "Evidence of Returns to Schooling in Africa from Household Surveys: Monitoring and Restructuring the Market for Education," Journal of African Economies, 13 Suppl. 2, 95-148.

Staiger, Douglas and James H. Stock (1997), "Instrumental Variables Regression with Weak Instruments," Econometrica, 65(3), 557-586

Stock, James H. and Motohiro Yogo (2005), "Testing for Weak Instruments in Linear IV Regression.” Ch. 5 in J.H. Stock and D.W.K. Andrews (eds), Identification and Inference for Econometric Models: Essays in Honor of Thomas J. Rothenberg, Cambridge University Press. 